
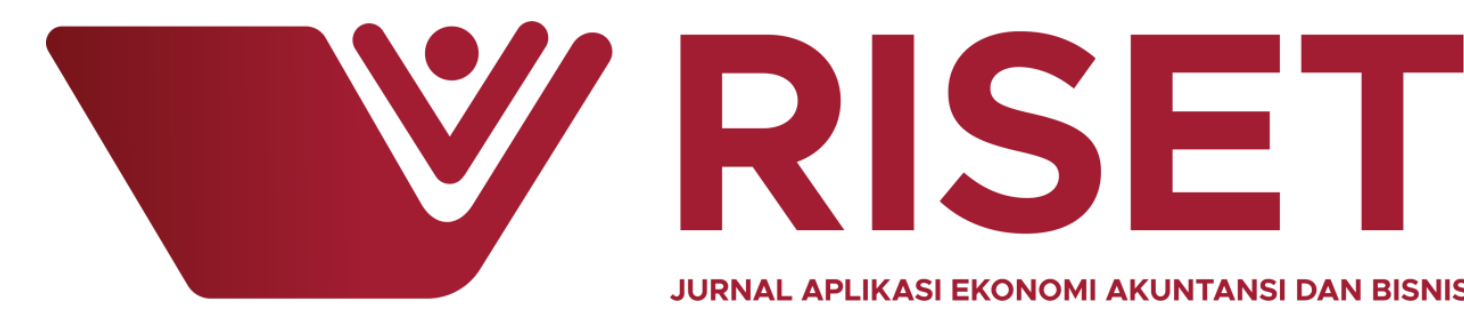

JURNAL APLIKASI EKONOMI AKUNTANSI DAN BISNIS

\title{
Macro economics: Liquidity, Solvency, and External Factor as Determinant of Government Bond Index Yield (INDOBEXGB) with The Vector Error Correction Model (VECM)
}

\author{
Nurlia Rahmatika ${ }^{1)}$, Muhamad Noer Fachmi ${ }^{2)}$ \\ 1) Kementerian Ketenagakerjaan, ${ }^{2)}$ Mandiri Healthcare
}

INFO ARTICLES
Macroeconomics:
Liquidity, Solvency, and
External Factor as
Determinant of
Government Bond Index
Yield (INDOBEXGB)
with The Vector Error
Correction Model
(VECM)

Submitted:
09- March - 2020
Revised:
20 - May - 2020
Accepted:
25 - September - 2020

\begin{abstract}
This research aims to analyze several variables such as macroeconomics variables and volatility index to yield on the government bond index. The macroeconomic indicators studied are consumer price index, B.I. Rate, money supply, foreign reserve, exchange rate, Indonesia total debt, and external factor volatility index S\&P 500. The period of this research conducted using secondary data from January 2012 until December 2017. This research uses the Vector Error Correction Model (VECM) method because cointegration exists between variables, indicated by Trace Statistic and Max-Eigenvalue statistic, which is bigger than the Critical Value. The result of the analysis shows that B.I. Rate, money supply, Indonesia total debt, and volatility index S\&P 500 positively influence yield government bond index INDOBEXGB.

In contrast, the consumer price index, foreign reserve, and exchange rate negatively affect yielding government bond index INDOBEXGB. The policy implication on the yield of state bonds is useful for the government as the monetary authorities to determine the number of bonds issued and front-loaded or wait and see a strategy in issuing bonds. It is helpful for the corporate issuer to determine the cost of funds for corporate bonds issued.
\end{abstract}

Keywords: Consumer Price Index, B.I. Rate, Money Supply, Foreign Reserve, Exchange Rate, Indonesia Total Debt, Volatility Index S\&P 500, Yield on Government Bond Index (INDOBEXGB), Vector Error Correction Model.

\section{INTRODUCTION}

One of the investment facility that is available to be chosen by an investor nowadays is investing in the financial market (financial market) which consists of the capital market (capital market) and money market (money market) (Bodie, Kane, \& Marcus, 2014). The capital market is one of the investment instruments that has experienced rapid 
development currently. According to (Permata \& Ghoni, 2019 ), the capital market's role as a source of corporate funding, which has implications for the country's economy, is not just an alternative but has become the primary source of funding. Funds offered in the capital market through several corporate actions such as initial public offering (IPO), a listing of new shares (rights issue), and bond issuance are considered far more efficient than funding obtained by the company from bank loans. In the capital market, there are instruments traded, such as securities that are equity, securities that are debt or bonds, derivative securities, and securities in the form of mutual funds. Based on the issuer or issuer, bonds are divided into three, namely government bonds (Government Bond), municipal bonds (Municipal Bond), and private corporate bonds (Corporate Bond) (Aenatun \& Subkhan, 2018). Government bonds are still more attractive to investors than corporate bonds because they are considered risk-free (Default risk-free) and provide investors with opportunities to diversify their portfolios to minimize investment risk. Investors believe the bond principal will be paid in full on time. Government bonds are used to finance government needs in developing the country and cover the state budget's debt deficit. Data for the past five years shows that the portion of Indonesian Government debt is dominated by Government Securities (bonds), where

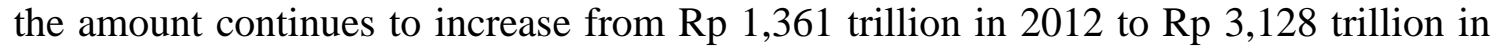
2017 (Direktorat Jenderal Pengelolaan Pembiayaan dan Risiko, 2018). Through the Ministry of Finance and the DJJPR OJK, the government always tries to prepare and update the rule of law and infrastructure supporting the bond market in stages such as the formation of the INDOBexGB state bond index on August 10, 2009. The existence of the bond index in Indonesia can still be very little in terms of variation, presence, and use. OTC (traded bond markets over The Counter), where price transparency and market liquidity are relatively low, makes it challenging to calculate bond market movements' performance and trend. The existence of bond indices such as INDOBeX, INDOBexCB, and INDOBexGB greatly facilitates market players in assessing the bond market's performance that is reliable, credible, and objective in describing the actual state of the Indonesian bond market and strengthening the growth of the bond market in Indonesia. Yield INDOBexGB as the only yield bond index representing the state bond market in Indonesia, be interesting to study more exceedingly to see how the characteristics of the movement patterns yield of the state bond index the determinant factor.

(Purwanti \& Purwidianti, 2017) stated that the shorter the bond period, the more attractive investors would be. Bonds that have shorter terms are considered to have a smaller risk. The risk will be offset by the yield obtained; a smaller risk will lower risk than bonds with high risk. In general, bond prices are affected by changes in results, the costs and yields of these bonds are interconnected, and the relationship appears reversed or negative. An increase in output will reduce bond prices, and a decrease in production will raise bond prices (Sihombing, Siregar, Manurung, \& Santosa, 2012). Several domestic macroeconomic indicators such as the Consumer Price Index, interest rates, money supply, foreign exchange reserves to the rupiah exchange rate can potentially affect the movement of bond yields. Empirically, these factors proved to affect the capital market's state several countries expressed (Tandelilin 2010). Namely, the development of the gross domestic product (GDP), interest rates, inflation rates, and exchange rates are macroeconomic indicators that can affect the yield or yield bond. In addition to macroeconomic variables, the S\&P 500 Volatility Index is also thought to influence the movement of bond yields. (Sihombing, 2014) in his research showed that in general, Volatility Index shocks, on the one hand, caused an increase in slope and levels yield bond both short and long term. 


\section{LITERATURE REVIEW}

\section{Yield Bonds (Yield to Maturity)}

Yield to Maturity (YTM) is a parameter to determine the number of returns to be received by the investor if the holding bonds to maturity. The author used this type of yield in this study, calculated by IBPA on the index of state bonds (INDOBexGB). The following formula can calculate YTM:

In the bond clause, it is mentioned that the issuer has a right to buy back all or some part of the bonds issued on the market:

$$
\begin{aligned}
& \text { YTM approximation }=\frac{C+\frac{R-P}{n}}{\frac{R+P}{2}} \times 100 \% \\
& \text { C: Coupon } \\
& \text { F: Nominal Value (Face Value) } \\
& \text { P: Market Value Bonds } \\
& \text { n: Period of Time (Time to Maturity) }
\end{aligned}
$$

\section{Indonesia Government Bonds Index (INDOBexGB)}

INDOBeX is part of the deepening of the market (market deepening) on the bond market Indonesia and answering the needs of a market indicator that objective, credible and reliable, and reflect the Indonesian bond market conditions are proper. INDOBeX became the first bond index in Indonesia issued using fair market prices and yields daily by the IBPA securities price valuation agency on state and corporate debt instruments denominated in rupiahs listed on the IDX. INDOBeX is divided into three types of indexes as follows:

i) INDOBeX COMPOSITE (INDOBex) is a bond index consisting of Government Securities (SBN) with coupons fixed-rate, Government Sharia Securities (SBSN) Ijarah contracts, Corporate Bonds with coupons fixed-rate and Corporate Sukuk Ijarah contract;

ii) INDOBeX GOVERNMENT (INDOBexGB) is a bond index consisting of Government Securities (SBN) with coupons fixed-rate and State Sharia Securities (SBSN) Ijarah contracts;

iii) INDOBeX CORPORATE (INDOBexCB) is a bond index consisting of Corporate Bonds with coupons fixed-rate and Corporate Sukuk Ijarah contracts. Each type of INDOBeX index above has five kinds of index calculation, which is:

Total Return (T.R.): The rate of return for all bonds, which is calculated based on the increase/decrease in the bond market price, accumulated accrued interest, and acquisition annual coupons that reinvested.

Clean Price (C.P.): The price movement of (price) all of the bonds are calculated based on the increase/decrease in bond market prices without taking into account the accumulated accrued interest (accrued interest).

Gross Price (G.P.): The price movement (price) of all of the bonds is calculated based on the increase/decrease in bond prices, taking into account accumulated interest earned runs (accrued interest).

Effective Yield (E.Y.): The movement of the yield rate of (yield) the overall bond, which is calculated based on the increase/decrease in the level of bond yields and has taken into account the accrued accumulation interest. This type of calculation is used in the INDOBexGB variable in the study. 
Gross Yield until Redemption (G.Y.): The movement of the rate of return (yield) bonds is calculated based on the overall increase/decrease in yields, bond the accumulated interest earned runs (accrued interest), and the duration of the bond.

\section{Money Supply (M2 or JUB)}

Money supply in the broadest sense is M1 plus quasi money (sometimes also called Near money), namely (short) time deposits, overnight loans between banks, savings, and domestic private currency accounts (Putong, 2015). All of the macroeconomic variables studied (Jurkšas \& Kropienè, 2014, the money supply has the most significant influence on government bonds' price. An increase in the money supply can pose risks to bonds, especially the risk of rising interest rates, which will increase the expected return and yield of state bonds. (Akbari \& Sentosa, 2019) also found that the money supply M2 had a positive but not significant effect on Indonesian bond yields. While the findings (Sihombing \& Sundoro, 2017) indicate that an increase in the money supply will increase liquidity, it will increase bonds' purchasing power and price. Rising bond prices led to a decrease in yields short-term bonds and yields long-term bonds. So it was concluded that an increase in the money supply would reduce the yield curve.

\section{Consumer Price Index (CPI)}

The consumer price index is a general parameter that is usually used in the formation of inflation indicators. As is known with inflation is a phenomenon of the overall increase in prices of goods and services continuously for a certain period, mainly in the community's basic needs. Some other price indexes can also measure inflation, such as the wholesale Price Index and the GNP deflator. In research (Jurkšas \& Kropienė, 2014) found that inflation can be a picture of the quality of how a country regulates its economy. The CPI reflects consumption expenditure, an increase in the CPI will reduce consumption expenditure due to falling real consumption values, and slow the economy. An economic slowdown will increase risks that have an impact on increasing yield.

\section{B.I. Rate (BIR)}

Since the beginning of July 2005, Bank Indonesia has used the B.I. Rate as a reference for interbank money market interest rates and longer-term interest rates (12 months). The B.I. The rate becomes a policy interest rate that reflects the stance or stance monetary policy set by Bank Indonesia. Also, it publicly announced at each monthly Board of Governors' Meeting. It is applied to financial operations through liquidity management of the money market to achieve monetary policy's operational targets. However, since August 19, 2016, the government changed its benchmark interest rate to the BI-7 Days R.R. Rate to deepen the financial market. Because the BI-7 Day R.R. Rate has a stronger relationship to money market interest rates that reflects the real money market mechanism with a short (7 days) period and is transactional in the market. Changes in the B.I. Rate or the BI-7 Days R.R. Rate are set consistently and gradually in multiples of 25 basis points (bps).

\section{Rupiah Exchange Rate Against Dollar (USD Exchange Rate)}

The exchange rate is one of the benchmarks used to assess the economic strength of a country. Besides, the exchange rate can also be interpreted as the amount of domestic money needed to buy or obtain a foreign exchange (Sukirno, 2015). In this study, the authors use exchange rate data from the Rupiah exchange rate against the U.S. Dollar. (Mankiw, 2018) in his book describes the exchange rate (exchange rate) or the exchange rate is the price level agreed upon by residents of the two countries to trade with each 
other. Economists differentiate the exchange rate into two, the nominal exchange rate and the real exchange rate. The nominal exchange rate is the relative price of the two countries' currencies, while the real exchange rate is the comparable price of goods between the two countries. Meanwhile, according to (Salvatore 2012), the exchange rate is defined as the price of foreign currencies in domestic currency units.

\section{Foreign Exchange Reserves (CD)}

According to Bank Indonesia, foreign exchange reserves are reserves in foreign currency units managed by the central bank to meet its financial obligations due to international transactions (reserve currency). The country's foreign exchange reserves are indicators that show a country's economy's strength and weakness. Bank Indonesia manages foreign exchange reserves based on Law no. 23 of 1999 article 13. The management is carried out through various types of foreign exchange transactions, such as selling, buying, and placing foreign exchange, gold, and securities in cash or futures, including lending the management of foreign exchange reserves based on the principle of obtaining optimal income. The depletion of foreign exchange reserves will cause rupiah speculation from speculators. According to (The World Bank, 2011), foreign exchange reserves' role is to protect the country from external shocks, an essential factor in assessing creditworthiness and the credibility of policies in general, and the need for liquidity to maintain exchange rate stability.

\section{Total Government Debt}

Government debt is part of fiscal policy (APBN), which is part of the overall economic management policy. Government debt is a consequence of the state budget deficit posture, in which state revenues are smaller than state spending. (Dailami, 2011) analyzes the risk of default on external government debt positively influencing the spread of corporate bond yields in emerging markets. Mansoor Dailami believes that increasing country risk represents the primary source of policy concerns and market anxiety because of the hidden dynamics between state and corporate debt. It can create negative feedback once an investor loses confidence in the government's ability to use public finances to stabilize the economy. Or provide safety nets for companies in trouble.

\section{Volatility Index S\&P 500}

(Sihombing, 2014) in his research explained that Dueker first presented volatility in the stock market as a barometer of uncertainty in financial markets in 1999. The results of a study conducted by (Purba, 2018), (Presbitero, Ghura, Adedeji, \& Njie, 2015), (Bellas, Papaioannou, \& Petrova, 2010) show the magnitude of the influence of the S\&P 500 Volatility Index or VIX as a proxy of uncertainty factors in global financial markets on changes in investors' risk appetite to provide a significant positive correlation on yield spread. (Purba, 2018) found a significant positive effect of VIX on the spread of sovereign bonds in 6 regional countries in East Asia (China, Indonesia, Malaysia, the Philippines, Thailand, and Vietnam) and five regional countries in Latin America and the Caribbean (Brazil, Colombia, Ecuador, Mexico, and Peru) a period of 2000Q12015Q4. The significant influence of VIX on the spread of sovereign bonds was also found (Bellas, Papaioannou, \& Petrova, 2010). Who conducted a study of the spreads of 14 emerging market sovereign bonds in 1997-2009 and (Presbitero, Ghura, Adedeji, \& Njie, 2015) in emerging markets and developing countries (EMDEs) issue state bonds at least once during the 1995-2013 period. 


\section{Research Hypotheses}

Hypothesis 1: Allegedly, there is a negative influence on the money supply (M2) to yield INDOBexGB

Hypothesis 2: Allegedly, there is a positive influence on the consumer price index to yield INDOBexGB

Hypothesis 3: Allegedly, there is a positive influence on the B.I. rate to yield INDOBexGB

Hypothesis 4: Allegedly, there is a positive influence on the exchange rate of USD to yield INDOBexGB

Hypothesis 5: Allegedly, there is a negative influence of foreign exchange reserves to yield INDOBexGB

Hypothesis 6: Allegedly, there is a negative influence of Total Government Debt to yield INDOBexGB

Hypothesis 7: Allegedly, there is a positive influence on the Volatility Index S \& $\mathrm{P}$ 500 to yield INDOBexGB

\section{METHODOLOGY}

Research data is monthly time series data from January 2012 to December 2017 (long term). The VAR (analysis tools vector Auto Regression) used if the data used is stationary, and there is no cointegration. While the Vector Error Correction Model (VECM), if the data used, is then found to be not fixed, but there is cointegration. In addition to the stationary test, determining the optimal lag, and testing the VAR model's stability, the diagnostic test is also performed using the impulse response method. Furthermore, variance decomposition to see Yield Indonesia Government BondIndex (INDOBexGB) response to shocks(shock)on other variables. Researchers will also do cointegration and causality tests to see the relationship between variables. In general, data variables are processed in the form of Natural Logarithms (Log), except the INDOBexGB variable and the B.I.A rate that has units in percentage. The study's dependent variable is the yield of the Indonesian Government Bond Index (INDOBexGB), while the rest are the independent variables of the study, as detailed in Table 1.

Table 1. Research Variable

\begin{tabular}{lcccc}
\hline No. & Variable Type & Symbol & Unit & Data Source \\
\hline 1. & Consumer Price Index (CPI) & IHK & Nominal & BPS \\
2. & B.I. rate & BIR & Percent & Bank Indonesia \\
3. & Exchange Rate USD & KURS & Rupiah & Bank Indonesia \\
4. & Total Money Supply (M2) & JUB & Rupiah & Bank Indonesia \\
5. & Foreign Exchange Reserves & CDV & US\$ & Bank Indonesia \\
6. & Total Government Debt & DEB & Billion US\$ & Bloomberg \\
7. & Volatility Index & VIX & Nominal & Bloomberg \\
8. & Yield INDOBexGB Index & IGB & Percent & IBPA \\
\hline
\end{tabular}

Source: Data processed from various sources, 2018.

\section{RESEARCH RESULTS AND DISCUSSION}

\section{Description of Research Variables}

As an index that is a measure of performance indicators and trends in Indonesia's government bond market movement. Meaning, INDOBexGB contains a collection of 
government bonds (SBN) with coupons fixed-rate (series F.R.) and Government Sharia Securities (SBSN) or Sukukijarah contract countries listed and listed on the Indonesia Stock Exchange and over the past nine years from 2009 to 2018. The type of calculation yield index used in this study is Effective Yield (E.Y.) because the yields describe the movement and volatility of the result. It means comprehensive for all government bonds in Indonesia. It is calculated based on an increase or decrease in yield bonds that have included the accrued interest's accumulated acquisition factor.

Table 2. Description of Research Variables

\begin{tabular}{lcccccccc}
\hline & IGB & IHK & BIR & JUB & CDV & KUR & DEB & VIX \\
\hline Mean & 7.321667 & 115.6890 & 6.607639 & 4099149. & 110.2387 & 12005.13 & 291567.7 & 15.20292 \\
Median & 7.505000 & 118.3800 & 6.500000 & 4174077. & 110.3950 & 12527.50 & 297315.5 & 14.23500 \\
Maximum & 9.690000 & 131.2800 & 7.750000 & 5419165. & 130.1960 & 14651.00 & 352985.0 & 28.43000 \\
Minimum & 5.190000 & 98.74000 & 5.500000 & 2852005. & 92.67100 & 8995.000 & 228761.0 & 9.510000 \\
Std. Dev. & 1.127355 & 10.46963 & 0.803630 & 740732.8 & 8.590728 & 1652.388 & 34741.59 & 3.544525 \\
Skewness & -0.23499 & -0.213529 & 0.077552 & 0.002583 & 0.417752 & -0.553426 & -0.151561 & 1.092923 \\
Kurtosis & 2.105663 & 1.691230 & 1.271291 & 1.814948 & 3.018615 & 1.819188 & 1.859727 & 4.861202 \\
& & & & & & & & \\
Jarque-Bera & 3.062164 & 5.685771 & 9.037475 & 4.213122 & 2.095237 & 7.858318 & 4.176313 & 24.72598 \\
Probability & 0.216302 & 0.058257 & 0.010903 & 0.121656 & 0.350772 & 0.019660 & 0.123915 & 0.000004 \\
& & & & & & & & \\
Sum & 527.1600 & 8329.610 & 475.7500 & $2.95 \mathrm{E}+08$ & 7937.186 & 864369.0 & 20992877 & 1094.610 \\
Sum Sq. Dev. & 90.23600 & 7782.537 & 45.85330 & $3.90 \mathrm{E}+13$ & 5239.843 & $1.94 \mathrm{E}+08$ & $8.57 \mathrm{E}+10$ & 892.0195 \\
& & & & & & & & 72 \\
Observations & 72 & 72 & 72 & 72 & 72 & 72 & 72 & 72 \\
\hline Source: EVin
\end{tabular}

Source: Eviews 9, data processed, 2018.

\section{Unit or Stationary Root Test}

The stationarity test results in table 3 show that almost all variables are non-stationary at the level, except for the S\&P 500 Volatility Index. The test results show this Augmented Dickey-Fuller (ADF), which is almost entirely insignificant at conventional real levels or Mc Kinnon's critical value $(1 \%, 5 \%$, and $10 \%)$. In other words, it can be said that hypothesis 0 , which states that there is a unit root (or data is not stationary), is accepted.

Table 3. Recapitulation Results of Stationary Test Variables Research

\begin{tabular}{ccccc}
\hline \multirow{2}{*}{ Variables } & \multicolumn{2}{c}{ Level } & \multicolumn{2}{c}{ First Difference } \\
\cline { 2 - 5 } & ADF Value & Description & ADF Value & Description \\
\hline IGB & -1.988996 & Not Stationary & -7.958814 & Stationary \\
IHK & -0.930814 & Not Stationary & -7.556587 & Stationary \\
BIR & -1.353494 & Not Stationary & -4.617052 & Stationary \\
JUB & -0.145728 & Not Stationary & -8.735492 & Stationary \\
CDV & -0.362924 & Not Stationary & -7.658847 & Stationary \\
KUR & -1.597892 & Not Stationary & -8.419866 & Stationary \\
DEB & -0.291052 & Not Stationary & -10.15962 & Stationary \\
VIX & -5.153787 & Stationary & -9.749056 & Stationary \\
\hline
\end{tabular}

Source: Eviews 9, the data processed in 2018.

\section{Determination of Optimal Lag}

The criteria for optimal lag selection carried out in several stages, namely by selecting in advance the maximum number of lags of the VAR / VECM model, which still provides stable model results. The stability of this model determined by the modulus value that is entirely smaller than one, and there is no inverse root value of the A.R. characteristic polynomial coming out of the unit circle (see Figure 1) (Lutkepohl, 1991). 
This stability test can be fulfilled until the 2nd lag; thus, the VAR model's maximum lag is 2 .

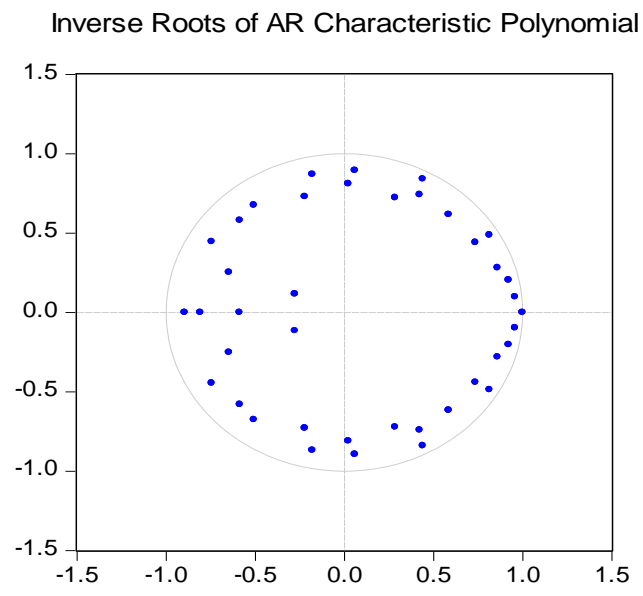

Figure 1. Polynomial Stationarity Stability Tests

Source: Eviews 9, data processed, 2018.

Test results for the optimal lag of the criteria and conditions shown in table 4. From the results of the tests that have been done, it can be seen that the recommended number of optimal lags is 1 (based on S.C. and H.Q. criteria) and 2 (based on L.R. and FPE criteria). In the end, based on the results of the selection of the optimal lag, it will have a model VAR / VECM of order 2.

Table 4. Optimal Lag Test Results

VAR Lag Order Selection Criteria

\begin{tabular}{ccccccl}
\hline \hline Lag & LogL & LR & FPE & AIC & SC & H.Q. \\
\hline \hline 0 & -2664.173 & NA & $6.06 e+24$ & 79.76637 & 80.02962 & 79.87054 \\
1 & -2153.454 & 884.2301 & $9.92 e+18$ & 66.43147 & $\mathbf{6 8 . 8 0 0 6 9 *}$ & $\mathbf{6 7 . 3 6 8 9 8}^{\star}$ \\
2 & -2082.049 & $\mathbf{1 0 6 . 5 7 4 7 ^ { \star }}$ & $\mathbf{8 . 6 0 e + 1 8 ^ { \star }}$ & 66.21042 & 70.68562 & 67.98127 \\
3 & -2030.961 & 64.05056 & $1.56 e+19$ & 66.59586 & 73.17703 & 69.20004 \\
4 & -1956.229 & 75.84731 & $1.77 e+19$ & 66.27550 & 74.96265 & 69.71303 \\
5 & -1855.639 & 78.06997 & $1.39 e+19$ & $65.18326^{*}$ & 75.97638 & 69.45412 \\
\hline \hline
\end{tabular}

Source: Eviews 9, data processed, 2018.

\section{Cointegration Test}

An equation is said to be cointegrated if its Trace Statistics value is greater than the critical value. From the test results, it can be seen that there is a cointegration relationship. The existence of a cointegration equation based on the Trace-statistical value at the 5\% real level with a Trace Statistics values more significant than the Critical Value. Thus the VAR model can be developed into a VECM model.

Table 5. Johansen's Cointegration Test Results

Unrestricted Cointegration Rank Test (Trace)

\begin{tabular}{ccccc}
\hline \hline $\begin{array}{c}\text { Hypothesized } \\
\text { No. of C.E. (s) }\end{array}$ & Eigenvalue & $\begin{array}{c}\text { Trace } \\
\text { Statistic }\end{array}$ & $\begin{array}{c}0.05 \\
\text { Critical Value }\end{array}$ & Prob. $^{* *}$ \\
\hline \hline None * & 0.508424 & 170.0578 & 159.5297 & 0.0117 \\
At most 1 & 0.411653 & 121.0582 & 125.6154 & 0.0918 \\
At most 2 & 0.317830 & 84.45798 & 95.75366 & 0.2317 \\
& & & 333 &
\end{tabular}




\begin{tabular}{lllll} 
At most 3 & 0.297704 & 58.06711 & 69.81889 & 0.2995 \\
At most 4 & 0.220814 & 33.68253 & 47.85613 & 0.5192 \\
At most 5 & 0.149677 & 16.46669 & 29.79707 & 0.6791 \\
At most 6 & 0.069975 & 5.279129 & 15.49471 & 0.7785 \\
At most 7 & 0.003958 & 0.273623 & 3.841466 & 0.6009 \\
\hline
\end{tabular}

Trace test indicates one cointegrating eqn(s) at the 0.05 level

* denotes rejection of the hypothesis at the 0.05 level

** MacKinnon-Haug-Michelis (1999) p-values

Source: Eviews 9, data processed, 2018.

\section{VECM Estimation Results}

From the VECM estimation test results (Table 6), the short-term and long-term estimation coefficients are obtained for equation yield the INDOBexGB index. Estimation results show six variables in the short term and one error correction variable that has a significant effect on the movement of theon the yield government bond index or INDOBexGB. The presence of substantial error correction parameters proves an adjustment mechanism from the short-term to the long-term. The amount of the adjustment or adjustment value from the short run to the long run is $-0,348,109$ percent. On the other hand, in the long run, six variables significantly affect the movement of the yield of the state bond index or INDOBexGB. It happens because when a variable reacts to other variables, it takes time (lag), and basically, the reaction of a variable to other variables occurs in the long run.

Table 6. VECM Estimation Results

\begin{tabular}{|c|c|c|c|}
\hline Variable & Coefficient & T-statistic & Description \\
\hline \multicolumn{4}{|c|}{ Short Term } \\
\hline $\mathrm{D}(\operatorname{IGB}(-2))$ & 0,709068 & {$[3,35630]$} & Significant \\
\hline $\mathrm{D}(\operatorname{IHK}(-2))$ & $-0,403830$ & {$[-3,09414]$} & Significant \\
\hline $\mathrm{D}(\mathrm{BIR}(-2))$ & 0,862632 & {$[1,39712]$} & Not Significant \\
\hline $\mathrm{D}(\mathrm{JUB}(-1))$ & $4,67 \mathrm{E}-06$ & {$[2,52886]$} & Significant \\
\hline $\mathrm{D}(\mathrm{CDV}(-1))$ & 0,050677 & {$[1,66608]$} & Not Significant \\
\hline $\mathrm{D}(\mathrm{KUR}(-1))$ & $-0,000768$ & {$[-2,05998]$} & Significant \\
\hline $\mathrm{D}(\mathrm{DEB}(-2))$ & $5,20 \mathrm{E}-05$ & {$[2,26879]$} & Significant \\
\hline $\mathrm{D}(\mathrm{VIX}(-2))$ & 0,042608 & {$[2,30758]$} & Significant \\
\hline $\mathrm{C}$ & 0,170090 & {$[1,25266]$} & Not Significant \\
\hline CointEq1 & $-0,348109$ & {$[-3,43011]$} & Significant \\
\hline \multicolumn{4}{|c|}{ Long Term } \\
\hline $\operatorname{IGB}(-1)$ & 1,000000 & - & - \\
\hline IHK $(-1)$ & 0,149324 & {$[1,09174]$} & Not Significant \\
\hline $\operatorname{BIR}(-1)$ & 2,933961 & {$[7,04009]$} & Significant \\
\hline $\operatorname{JUB}(-1)$ & $1,39 \mathrm{E}-05$ & {$[4,76788]$} & Significant \\
\hline $\operatorname{CDV}(-1)$ & $-0,86768$ & {$[-4,41246]$} & Significant \\
\hline KUR (-1) & $-0,002716$ & {$[-4,85775]$} & Significant \\
\hline $\operatorname{DEB}(-1)$ & 0,000104 & {$[3,92655]$} & Significant \\
\hline VIX $(-1)$ & 0,258077 & {$[4,43318]$} & Significant \\
\hline $\mathrm{C}$ & $-17,16413$ & - & - \\
\hline
\end{tabular}

Source: Eviews 9, data processed, 2018

The Consumer Price Index (CPI) variable in the second lag has a significant negative effect in the short term but $\mathrm{n}$ not a significant positive impact in the long run. It indicates that when there is an increase in CPI of 1 percent in the previous two years, it will reduce the INDOBexGB index yield by 0.403830 percent in the current year, but it 
will experience a long-term increase of 0.149324 percent. The CPI is a proxy for calculating the inflation rate. The inflation rate of a country can negatively or positively impact how high inflation is experienced. Suppose the inflation rate is still classified as mild inflation (lower than 10\%). In that case, this has the potential to have a positive impact on the economy because it can increase purchasing power, increase national income to be able to encourage economic growth in a country because it makes the population eager to work, save, and invest as in securities or the real sector. On the other hand, when there is a high rise in inflation, this can potentially lead to economic overheating that can make investors expect higher bond yields, so bond yields have increased.

B.I. The rate variable in the second lag is a not significant positive effect in the short term but significant positive in the long run. It means that when the Blincreases Rate by one percent in the previous two years period, the yield of the INDOBexGB state bond index will increase by 0.862632 percent in the current year and the long run by 2.933961 percent. The results of research conducted by (Bodie, Kane, \& Marcus, 2014) states that an increase in interest rates will affect bond yields in the short term compared to the long term so that the rise in interest rates can increase the yield curve of government bonds. Implementing tightening monetary policy, such as raising the discount rate, can increase the expectations of government bond yields.

The variable money supply in the second lag has a significant positive effect in the short and long term. It means that when there is an increase in the money supply in the market by one percent in the previous two years, it will increase the yield of the INDOBexGB state bond index by 4.67 percent in the current year and will increase in the long term by 1.39 percent. Simply put, an increase in the money supply can lead to a rise in interest rates and expected returns, which in turn will cause an increase in bond yields (Jurkšas \& Kropienè, 2014).

The foreign exchange reserve variable for the second lag is not a significant positive effect in the short term and shows a significant negative. Furthermore, this means that when there is an increase in foreign reserves or foreign exchange reserves by one percent in the previous two years, the yield index of the INDOBexGB sovereign bond will increase by 0.050677 percent in the current year, but also will decline by 0.8678 percent in the long run. Research conducted by (Muharam 2011) shows that the factors that can increase the risk of default on a government bond are liquidity crisis, including foreign exchange reserves, where there is a significant negative effect between foreign exchange reserves on yields or government bonds. It shows decrease yields in a government bond will accompany an increase in foreign exchange reserves.

The second lag's exchange rate variable shows a significant negative effect in the short and long term. It means that when there is an increase in the exchange rate (the rupiah weakens against the USD) by one percent in the previous year, it will have implications for decrease yield the INDOBexGB index by 0,000768 percent in the current year and 0.002716 percent in the long run. Appreciation of the rupiah exchange rate continuously without being accompanied by any depreciation (the USD exchange rate is declining) can harm Indonesia's trade balance, especially on the export side. The number of exports will decrease due to the price of Indonesian export goods becoming relatively more expensive. The competitiveness of Indonesian export products becomes increasingly uncompetitive in the international market.

The variable total government debt in the second lag shows a significant positive effect both in the short and long term. It shows that when there is an increase in total government debt of one percent in the previous two years, it will potentially increase the yield of the INDOBexGB state bond index by 5.20 percent in the current year and by 
0,000104 percent in the long run. High total government debt indicates that the supply of government bonds on the market increases, so investors expect higher yields on bonds, which has implications for increased profits in a government bond.

The last variable is the S\&P 500 Volatility Index, in the lag of these two variables show significant positive influence in the short and long term. It indicates that when the S \& $\mathrm{P}$ 500 Volatility Index increased by one percent in the previous two years, it will cause the yield or yield of INDOBexGB sovereign bonds to increase by 0.042608 percent in the current year and 0.258077 percent in the long run. The S\&P 500 Volatility Index is an index that describes the level of investor panic; the higher the S\&P 500 Volatility Index, this means that the level of uncertainty in the market is high, making investors panic.

\section{Impulse Respons Function (IRF)}

Figure 2 shows the shock of all the independent variables of one standard deviation of not giving a significant influence on yield bond index INDOBexGB country, except yield bond index INDOBexGB country itself. Statistically shows that shocks yield the INDOBexGB sovereign bond index of one positive standard deviation will increase the yield bond of 0.40 percent in the first month. While in the long term yield, the INDOBexGB sovereign bond index will increase in equilibrium by 0.36 percent in the nineteenth month to the thirtieth period.

Response to Cholesky One S.D. Innov ations

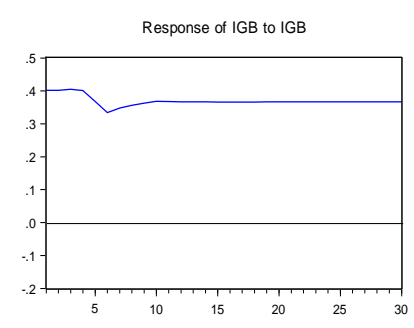

Response of IGB to BIR

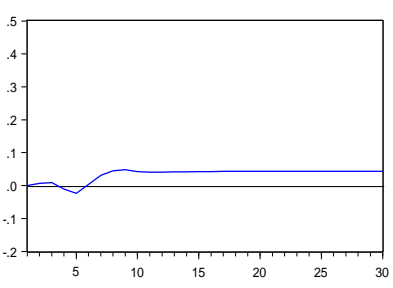

Response of IGB to IHK

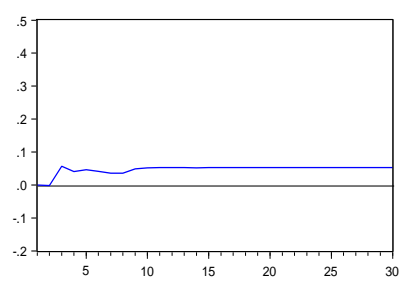

Response of IGB to KUR

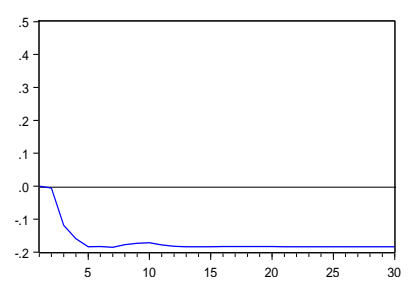

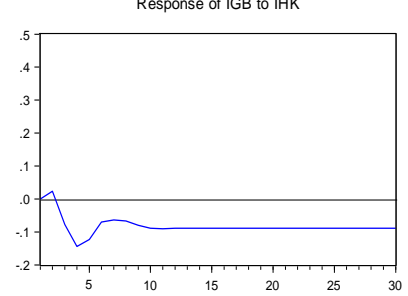

Response of IGB to VIX

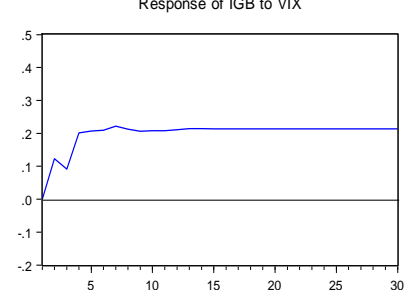

Response of IGB to CDV

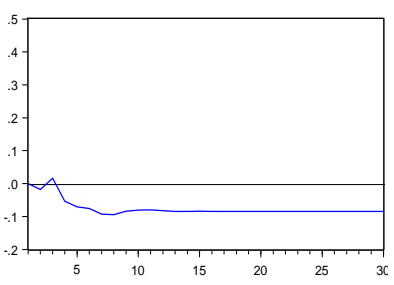

Response of IGB to JUB

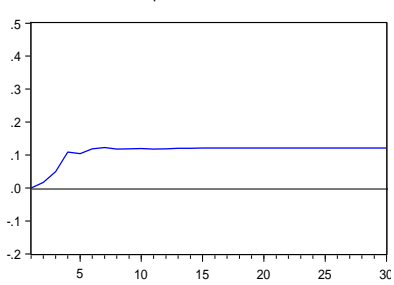

Figure 2. The response yield of the INDOBexGB index due to shocks (CPI, BIR, JUB, CDV, KUR, DEB, and VIX).

Statistically, the Consumer Price Index (CPI) shock of one standard deviation was responded positively in the second month by 0.023 percent, but then reacted negatively and caused the yield of the state bond index to decrease by 0.144 percent in the fourth month; this decline reaching equilibrium in the long run in the thirteenth month of 0.0890 percent. The B.I. The shock rate (BIR) of one standard deviation was responded negatively and caused the yield to the INDOBexGB index to decrease by 0.008 percent 
in the third month. The result reacted positively, and the output increased and reached a balance point in the tenth month of 0.042 percent. The shock of the money supply (JUB) of one standard deviation was responded positively by the yield government index of the INDOBexGBbonds. An increase in the money supply will increase the state bond index's yield in the seventh month by 0.122 percent and begin to achieve longterm stability by 0.120 percent in the thirteenth month. Foreign exchange reserve (CDV) shocks of one standard deviation were responded positively in the third month by 0.016 percent. Still, they responded negatively by yield the INDOBexGB sovereign bond index in the long run. The increase in foreign exchange reserves will reduce the growth of the state bond index in the fourth to the eighth month by 0.053 percent and 0.094 percent; the decline began to reach long-term stability by 0.083 percent in the ninth month. The rupiah exchange rate shock to the U.S. dollar (KUR) of one standard deviation responded negatively. It caused the INDOBexGB bond index to decrease in the fifth month by 0.184 percent and begin to achieve long-term stability of 0.183 percent in the fourteenth month. The total government debt shock of one standard deviation was responded positively. It caused the INDOBexGB bond index to increase in the third month by 0.056 percent and begin to achieve stability in the long term by 0.052 percent in the tenth month. The S\&P 500 Volatility Index shock of one standard deviation was responded positively and caused the INDOBexGB bond index to rise in the fourth month by 0.20 percent. Then in the seventh month, it also increased by 0.22 percent and began to reach a balance point in the twelfth month by 0.21 percent.

\section{Forecast Error Variance Decomposition (FEVD)}

Based on Table 7, the yield index of the state bond index (INDOBexGB) gave the largest contribution of 100 percent in the initial period. In the following period, the contribution of INDOBexGB began to decrease to 95.20 percent, followed by the B.I. Rate of $0.014 \%$, foreign exchange reserves of $0.091 \%$, total government debt $0.006 \%$, consumer price index $0.161 \%$, money supply $0.084 \%$, USD Exchange Rate $0.009 \%$, and the S\&P 500 Volatility Index of $4.432 \%$. If sorted, the variables that provide the largest to smallest contribution to the yield of the state bond index are INDOBexGB itself. The S\&P 500 Volatility Index, the USD Exchange Rate, the Amount of Money Circulating, the Consumer Price Index, Foreign Exchange Reserves, Total Government Debt, and the B.I. Rate. The biggest influence affecting the yield of INDOBexGB sovereign bonds came from the S\&P Volatility Index 500.

Table 7. Results of Variance Decomposition Bond Index

\begin{tabular}{rccccccccc}
\hline \hline Period & S.E. & IGB & BIR & CDV & DEB & IHK & JUB & KUR & VIX \\
\hline \hline 1 & 0.402186 & 100.0000 & 0.000000 & 0.000000 & 0.000000 & 0.000000 & 0.000000 & 0.000000 & 0.000000 \\
2 & 0.582831 & 95.20590 & 0.014219 & 0.091587 & 0.000683 & 0.161478 & 0.084044 & 0.009163 & 4.432927 \\
3 & 0.733696 & 90.55152 & 0.022927 & 0.106310 & 0.597257 & 1.212366 & 0.512878 & 2.640348 & 4.356395 \\
4 & 0.895771 & 80.77817 & 0.028335 & 0.428504 & 0.605060 & 3.417557 & 1.820547 & 4.953862 & 7.967963 \\
5 & 1.023749 & 74.72431 & 0.074814 & 0.805898 & 0.664496 & 4.070715 & 2.429231 & 7.031894 & 10.19864 \\
6 & 1.124054 & 70.80012 & 0.062734 & 1.118861 & 0.685683 & 3.767039 & 3.133562 & 8.501854 & 11.93015 \\
7 & 1.224032 & 67.79649 & 0.117721 & 1.514529 & 0.661824 & 3.446535 & 3.643870 & 9.475186 & 13.34384 \\
8 & 1.316271 & 65.96113 & 0.217052 & 1.820736 & 0.644000 & 3.237193 & 3.957469 & 10.01074 & 14.15168 \\
9 & 1.403176 & 64.73245 & 0.307023 & 1.956091 & 0.687758 & 3.173569 & 4.194279 & 10.33862 & 14.61021 \\
10 & 1.486808 & 63.78721 & 0.353838 & 2.038663 & 0.735123 & 3.185682 & 4.381501 & 10.54847 & 14.96952 \\
11 & 1.566464 & 62.97195 & 0.386392 & 2.095973 & 0.776650 & 3.202560 & 4.515440 & 10.80344 & 15.24760 \\
12 & 1.642934 & 62.22541 & 0.413897 & 2.154326 & 0.810628 & 3.203364 & 4.628695 & 11.05695 & 15.50673 \\
13 & 1.716906 & 61.54561 & 0.436681 & 2.214494 & 0.836512 & 3.202996 & 4.728507 & 11.27570 & 15.75950 \\
14 & 1.787662 & 60.97086 & 0.456905 & 2.265493 & 0.856599 & 3.203201 & 4.817312 & 11.45872 & 15.97090 \\
15 & 1.855609 & 60.47376 & 0.476377 & 2.308464 & 0.874685 & 3.203520 & 4.896435 & 11.61625 & 16.15051 \\
16 & 1.921148 & 60.04467 & 0.494049 & 2.347520 & 0.890432 & 3.201980 & 4.964787 & 11.75063 & 16.30593
\end{tabular}




\begin{tabular}{llllllllll}
17 & 1.984536 & 59.67155 & 0.510288 & 2.381623 & 0.904661 & 3.199575 & 5.023681 & 11.86782 & 16.44079 \\
18 & 2.046013 & 59.34508 & 0.524843 & 2.411033 & 0.917541 & 3.198174 & 5.075257 & 11.96984 & 16.55823 \\
19 & 2.105753 & 59.05487 & 0.537660 & 2.436719 & 0.929160 & 3.198246 & 5.120886 & 12.06035 & 16.66211 \\
20 & 2.163855 & 58.79490 & 0.548932 & 2.459466 & 0.939681 & 3.198841 & 5.161643 & 12.14191 & 16.75462 \\
21 & 2.220449 & 58.55960 & 0.558992 & 2.480028 & 0.949191 & 3.199312 & 5.198429 & 12.21594 & 16.83851 \\
22 & 2.275642 & 58.34615 & 0.568088 & 2.498813 & 0.957713 & 3.199509 & 5.231755 & 12.28318 & 16.91480 \\
23 & 2.329528 & 58.15190 & 0.576426 & 2.515966 & 0.965415 & 3.199569 & 5.262090 & 12.34438 & 16.98425 \\
24 & 2.382197 & 57.97468 & 0.584077 & 2.531641 & 0.972444 & 3.199626 & 5.289806 & 12.40013 & 17.04760 \\
25 & 2.433726 & 57.81239 & 0.591102 & 2.545990 & 0.978900 & 3.199712 & 5.315208 & 12.45111 & 17.10559 \\
26 & 2.484185 & 57.66325 & 0.597566 & 2.559161 & 0.984851 & 3.199803 & 5.338557 & 12.49797 & 17.15884 \\
27 & 2.533641 & 57.52564 & 0.603533 & 2.571308 & 0.990349 & 3.199891 & 5.360089 & 12.54122 & 17.20797 \\
28 & 2.582151 & 57.39826 & 0.609053 & 2.582551 & 0.995440 & 3.199978 & 5.380011 & 12.58126 & 17.25345 \\
29 & 2.629767 & 57.28000 & 0.614176 & 2.592985 & 1.000166 & 3.200068 & 5.398504 & 12.61844 & 17.29566 \\
30 & 2.676537 & 57.16991 & 0.618942 & 2.602697 & 1.004564 & 3.200156 & 5.415719 & 12.65305 & 17.33496 \\
\hline \hline
\end{tabular}

Source: Eviews 9, processed, 2018.

\section{CONCLUSIONS}

1. Shocks that occur in the Consumer Price Index (CPI) harm the state bond index (INDOBexGB) yield statistically. An increase in CPI indicates an increase in the money supply; when the money supply increases, investors' ability to set aside funds and invest in bonds also increases, yield the INDOBexGB government bond index has decreased due to the great demand for investment in bonds.

2. Shocks that occur in the B.I. Rate (BIR) positively influences the yield of the state bond index (INDOBexGB) statistically. An increase in the B.I. The rate will distort asset prices and reduce investment in government bonds. It is what then makes yields the country's bond increase. A tight monetary policy, such as B.I. that increases the discount rate or raises the B.I. Rate is considered to increase the expectation of bond yields.

3. Shocks that occur in the money supply (JUB) positively affect the yield of the state bond index (INDOBexGB) statistically. The increase in the money supply will increase liquidity, which further makes the central bank have the potential to increase the benchmark interest rate. For example, to reduce liquidity in the market, increasing interest rates can make investors move funds from bonds to banking products such as deposits so that bond prices will tend to fall (bond yields rise).

4. Shocks that occur in foreign exchange reserves (CDV) negatively influence the yield of the state bond index (INDOBexGB) statistically. An increase in foreign exchange reserves (which is a proxy for a country's foreign exchange liquidity) will increase capital flows from abroad, thereby increasing bond purchases and lowering government yields bond.

5. Shocks that occur on the rupiah's exchange rate against the dollar (KUR) have a negative influence on the yield of the state bond index (INDOBexGB) statistically. An increase in the exchange rate means that the rupiah has weakened against the dollar (depreciation). The weakening of a country's currency will potentially cause the money to be undervalued and further make investment returns more attractive to foreign investors. As a risk-free instrument (risk-free), then the selection of government bonds is a priority for the foreign investors to invest in Indonesia so that yields bond will fall.

6. Shocks that occur in Total Government Debt (DEB) have a positive effect on the state bond index (INDOBexGB) statistically. An increase in total government debt indicates that the supply of government bonds on the market increases; when the 
supply of bonds increases, this can increase the yield of government bonds because investors expect higher results.

7. Shocks that occur in the S\&P 500 Volatility Index have a positive effect on the yield of the state bond index (INDOBexGB) statistically. An increase in the S\&P 500 Volatility Index reflects market risk when an increase in the S\&P 500 Volatility Index indicates uncertainty and risk in the market are increasing, which investors will then respond to by taking action on bond sales. It is what ultimately led to increase yields in state bonds.

\section{REFERENCES}

Aenatun, N., \& Subkhan, M. (2018). Faktor-Faktor Yang Mempengaruhi Prediksi Peringkat Obligasi Ditinjau Dari Faktor Profitabilitas, Likuiditas, Leverage, Ukuran Perusahaan, Jaminan, Dan Umur Obligasi Pada Perusahaan Manufaktur Di Bursa Efek Indonesia. Yogyakarta: STIE Widya Wiwaha.

Akbari, F., \& Sentosa, S. U. (2019). Pengaruh Faktor Makroekonomi Dan Kebijakan Moneter Negara Maju Terhadap Yield Obligasi Indonesia. Jurnal Kajian Ekonomi dan Pembangunan, Vol.1, No.2, Mei 2019, 287 - 300.

Bellas, D., Papaioannou, M., \& Petrova, I. (2010). Determinants of emerging market sovereign bond spread fundamentals vs. financial stress. IMF Working Paper, 10(281): 1-23.

Bodie, Z., Kane, A., \& Marcus, A. J. (2014). Investments, 10th ed. New York (U.S.): McGraw-Hill.

Dailami, M. (2011). Sovereign Debt Distress and Corporate Spillover Impacts. Dalam Sovereign Debt and The Financial Crisis, Will This Time Be Different? (page. 101-126). Washington, DC: International Monetary Fund (IMF).

Jurkšas, L., \& Kropienè, R. (2014). Macroeconomic determinants of Lithuanian Government Security Prices. Ekonomika, Vol. 93(4), 7-23.

Permata, C., \& Ghoni, M. (2019 ). Peranan Pasar Modal Dalam Perekonomian Negara Indonesia. Jurnal AkunStie (JAS), Vol. 5, No. 2 Desember , 50-61.

Presbitero, A., Ghura, D., Adedeji, O., \& Njie, L. (2015). International Sovereign Bonds by Emerging Markets and Developing Economies: Drivers of Issuance and Spreads. IMF Working Paper WP/15/275, 1-27.

Purba, I. (2018). Pengaruh Variabel Ekonomi Makro Terhadap Yield Spread NegaraNegara Di Asia Timur, Amerika Latin Dan Karibian. Indonesian Treasury Review Vol.3 No.1, 61-67.

Purwanti, P., \& Purwidianti, W. (2017). Pengaruh Peringkat Obligasi, Tingkat Suku Bunga Sertifikat Bank Indonesia, Rasio Leverage, Ukuran Perusahaan, Umur Obligasi, Dan Tingkat Inflasi Pada Imbal Hasil Obligasi Korporasi Di Bursa Efek Indonesia. Jurnal Manajemen dan Bisnis MEDIA EKONOMI Vol. XVII, No.1 Januari, 13-24.

Salvatore, D. (2012). Ekonomi Manajerial Dalam Perekonomian Global, Buku 2. Jakarta: Salemba Empat.

Sihombing, P. (2014). Determinan Yield Curve Surat Utang Negara (SUN). Dalam Disertasi. Bogor: Institut Pertanian Bogor.

Sihombing, P., \& Sundoro, H. (2017). Pengaruh Faktor Makroekonomi Dan Likuiditas Terhadap Yield Curve Obligasi Pemerintah Indonesia. Media Ekonomi Vol. 25 No. 2 Oktober, 117-132.

Sihombing, P., Siregar, H., Manurung, A. H., \& Santosa, P. W. (2012). Analisis Pengaruh Makroekonomi terhadap Term Structure Interest Rate Obligasi 
Riset: Jurnal Aplikasi Ekonomi, Akuntansi dan Bisnis Vol. 2 No. 2,

Pemerintah (SUN) Indonesia. Journal of Capital Market and Banking. Vol.1 No.2.

Tandelilin, E. (2010). Portofolio dan Investasi Teori dan Aplikasi, Edisi Pertama. Yogyakarta: Kanisius.

The World Bank. (2011). Sovereign Debt And The Financial Crisis, Will This Time Be Different? Washington, D.C.: The World Bank. 